Egyptian Journal of Aquatic Biology \& Fisheries

Zoology Department, Faculty of Science,

Ain Shams University, Cairo, Egypt.

ISSN $1110-6131$

Vol. 24 (7): 725 - 739 (2020)

www.ejabf.journals.ekb.eg

\title{
Mass production of Arthrospira platensis on the livestock manure for use as a protein source in animal feed
}

\author{
Eman Ibrahim Abdel-Aal ${ }^{1, *}$ and Jelan Mofeed ${ }^{2,3}$ \\ 1; National Institute of Oceanography and Fisheries, NIOF, Cairo \\ 2; Faculty of Science, King Salman International University, Sinai, Egypt \\ 3; Faculty of Fish Resources, Suez University, Suez, Egypt \\ *Corresponding Author: emanibrahim2002@gmail.com
}

\section{ARTICLE INFO}

Article History:

Received: Oct. 23, 2020

Accepted: Nov.26, 2020

Online: Dec. 5, 2020

Keywords:

Arthrospira platensis EG5,

biomass,

livestock manure,

protein,

amino acid

\section{INTRODUCTION}

The biotechnological applications of Arthrospira platensis require intensive cultivation for mass production, taking into consideration the economic perspectives. The livestock manure was tested for the cultivation of $A$. platensis EG5 for economic production of biomass and protein. The manure concentrations of 1.6, 3.2, 6.4 and $12.8 \mathrm{~g} \mathrm{~L}^{-1}$ significantly increased $(P \leq 0.5)$ the biomass by $19.6,44.9,29.8$, and $18.8 \%$, compared to the control Zarrouk's medium. Meanwhile, the control medium supported protein production more than manure media but with a nonsignificant difference $(P \leq 0.05)$ with the manure concentrations of 3.2 and $6.4 \mathrm{~g} \mathrm{~L}^{-1}$, where it reached $50 \pm 5.4$ and

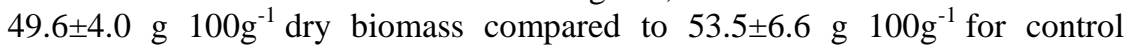
medium. The metals; $\mathrm{Fe}, \mathrm{Zn}, \mathrm{Cu}, \mathrm{Mg}$ and $\mathrm{Mn}$ were measured in $A$. platensis EG5 cultivated on different manure media and their concentration range was in good agreement with many animal feed requirements as reported by NRC. The biomass and protein productivity of A. platensis EG5 on a continuous open pond system using manure medium $\left(3.2 \mathrm{~g} \mathrm{~L}^{-1}\right)$ was studied for three continuous culturing cycles and maintained mean biomass of $1.11,1.42$

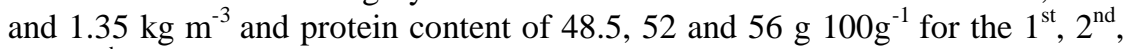
and $3^{\text {rd }}$ harvested biomass. The biomass of $A$. platensis EG5 cultivated on manure medium was a good source of the essential amino acids; arginine, leucine, isoleucine, lysine, methionine, phenylalanine, threonine, and valine with concentrations comparable to the amino acids requirements of many animals as reported by the NRC. In conclusion, the cultivation of $A$. platensis EG5 on livestock manure for biomass and protein production maintained promising results. Therefore, we would recommend future detailed studies on using the manure commercial-scale cultivation of microalgae as a protein source to enhance the nutritional quality of fish and animal diets economically and sustainably.

\section{INTRODUCTION}

Undernutrition forms a public health dilemma, especially in developing countries, where, the growing population requires economic nutritional alternatives to meet human needs. Therefore, researchers and scientists have to develop novel renewable and economical solutions to prevent malnutrition; hence the attention has been turned to 
microalgae (Khatoon and Pal, 2015). Using of algae as a food for both humans and animals is one of these solutions because this valuable group of organisms contains a high percentage of proteins, carbohydrates, and lipids in addition to varieties of mineral and vitamins (Renaud et al., 1999; Pulz and Gross, 2004; Becker, 2007; Abdel-Hamid et al., 2015a; Mofeed et al., 2019). Algae became a powerful raw material for many applications in our life not only as food and feed (Becker, 2004; Pulz and Gross, 2004; Abdel-Hamid et al., 2016) but also in therapeutic pharmaceuticals (Bansemir et al., 2006; Madkour et al., 2012a, 2019; Abdel-Aal et al., 2015; Deyab et al., 2020), nutritional and cosmetic industries (Pulz and Gross, 2004), in addition to its applications in the production of biofuel (Abdel-Aal, 2013; Abdel-Aal and Mofeed, 2015; AbdelHamid et al., 2015b; Abdel-Hamid et al., 2019), bioplastic and purification of waste or even as a biomarker for different types of pollutants in aquatic habitats (ShaabanDesouki et al., 2004; Ward et al., 2012; Mofeed and Mosleh, 2013; Abdel-Hamid et al., 2014, 2017; Mofeed, 2017; Abdel Gawad and Abdel-Aal, 2018).

Arthrospira platensis Gomont 1892 is the most applicable algae throughout the recent decades due to the fact that in terms of the chemical composition it is a very rich food source of both macro- and micronutrients including high-quality protein content up to $70 \%$ of the dry weight, essential fats (e.g., gamma-linolenic and oleic acids), essential amino acids, vitamins (e.g., B12), $\beta$-carotene, lipids and polysaccharides with a distinctive high content of calcium, iron, phosphorous, minerals, sulfated and phycocyanin, besides its antioxidant capacity (Phang $\boldsymbol{e t}$ al., 2000; Babadzhanov $\boldsymbol{e t}$ al., 2004; Abdel-Daim et al, 2015, 2020; Mofeed, 2019). Moreover, A. platensis showed neither chronic nor any acute toxicity or even harmful effects, making it safe to use as part of diets for human food and as a dietary supplement of poultry and fish feed production as a non-conventional high protein source (Habib et al., 2008; El-Sheekh $\boldsymbol{e t}$ al., 2014). Arthrospira platensis as many microalgae can be cultivated in both closed and open systems to get a commercial value. Cultivation of $A$. platensis needs basic elements such as phosphorus, nitrogen and carbon (Davis, 1977), with a significant high need to both bicarbonate and carbonate (Binaghi et al., 2003). The cost of A. platensis biomass productivity can vary according to the used nutritional source, therefore, it was cultivated in the large farms using fertilizers as nutrient sources (Kendirli, 2010; Madkour et al., 2012b). Recently the agro-industrial wastes were used as raw materials in the economic production of $A$. platensis (Markou $\boldsymbol{e t}$ al., 2018). There are some pioneering attempts in this field, such as the use of sugarcane mills residues in the cultivation of Arthrospira to produce a protein (Pelizer et al., 2015). Another way by utilization of the disposals of pig and chicken farms, as the source of nutrients, in the production of Spirulina (Ungsethaphand et al., 2007, 2009). Furthermore, Cheunbarn and Peerapornpisal (2010) utilized wastewaters with its carbonized substances to produce algal biomass. The biomass which is obtained from the cultivation on animal farms wastes can be used in animal feed as being a valuable nutrient source (Chaiklahan $\boldsymbol{e t}$ al., 2010). The livestock manure characterized by the high organic and mineral load; represented mainly by nitrogen $(\mathrm{N})$ and phosphorus $(\mathrm{P})$ (Petersen et al., 2007), which are very important components for the cultivation of microalgae. There are few published studies about the cultivation of $A$. platensis on livestock manure as a source of nutrients (e.g. Mitchell and Richmond, 1988). Therefore, the present study aimed to examines the efficiency of 
using large animal manure for mass production of $A$. platensis vis the conventional cultivation process to reduce the cost of biomass and protein production.

\section{MATERIALS AND METHODS}

\section{Preparation of livestock manure}

The cattle manure was obtained from a livestock farm near Mansoura city (Egypt). The manure was dried in the open air for two days and then oven-dried at $100^{\circ} \mathrm{C}$ until constant weigh. The dried manure wasground to a fine powder and stored in a refrigerator at $-20^{\circ} \mathrm{C}$.

\section{Preparation and analysis of manure stock solution}

A manure stock solution was prepared at a concentration ratio of $1.0 \mathrm{~kg}$ manure powder: $5 \mathrm{~L}$ distilled water, autoclaved at $121^{\circ} \mathrm{C}$ for $15 \mathrm{~min}$, filtrated through cotton and Whatman No. 1 filter papers, re-autoclaved and then kept at $4^{\circ} \mathrm{C}$. The concentrations of some nutritionally important elements (Table 1) were determined in the prepared manure stock solution to evaluate its potential as cultivation medium for microalgae including; total inorganic nitrogen (TIN), dissolved phosphorus (DP), iron (Fe), magnesium $(\mathrm{Mg})$, zinc $(\mathrm{Zn})$, and copper $(\mathrm{Cu})$. All analyses were carried out according to APHA (2005).

Table 1: Element constitutes of manure stock solution.

\begin{tabular}{lc}
\hline Parameters & Concentration \\
\hline $\mathrm{TIN}, \mathrm{g} \mathrm{L}^{-1}$ & 33.6 \\
$\mathrm{DP}, \mathrm{g} \mathrm{L}^{-1}$ & 6.30 \\
$\mathrm{Fe}, \mathrm{g} \mathrm{L}^{-1}$ & 1.38 \\
$\mathrm{Mg}, \mathrm{g} \mathrm{L}^{-1}$ & 3.98 \\
$\mathrm{Cu}, \mathrm{mg} \mathrm{L}^{-1}$ & 6.18 \\
$\mathrm{Zn}, \mathrm{mg} \mathrm{L}^{-1}$ & 6.76 \\
\hline
\end{tabular}

\section{Test microalga and growth conditions}

The cyanobacterium strain Arthrospira platensis EG5 (NCBI: txid 2175805) was obtained from the Hydrobiology Laboratory, Freshwater and Lakes Division, National Institute of Oceanography and Fisheries, NIOF, Egypt. The strain was grown in liquid Zarrouk's medium (Zarrouk, 1966) with a continuous light intensity of $3.5 \pm 0.2$ Klux at $28 \pm 2^{\circ} \mathrm{C}$.

\section{Experiment Design}

Six treats of manure media were prepared at the concentrations illustrated in Table 2, to evaluate the mass production potentiality of the animal manure. The Zarrouk's medium was used as a control medium for growth of A. platensis EG5. The $\mathrm{pH}$ of the prepared media was adjusted to $9.5 \pm 0.5$ by $\mathrm{NaHCO}_{3}$ and the salinity to $1.0 \mathrm{~g} \mathrm{~L}^{-1}$ by $\mathrm{NaCl}$. The nitrogen concentration in the prepared manure media ranged from 67.2 to $2150 \mathrm{mg} \mathrm{L}^{-1}$, while that of Zarrouk's medium was $400 \mathrm{mg} \mathrm{L}^{-1}$. Meanwhile, the phosphorus concentration in the prepared manure media ranged from 12.6 to $403 \mathrm{mg} \mathrm{L}^{-1}$ and in Zarrouk's medium was $88.8 \mathrm{mg} \mathrm{L}^{-1}$. The prepared media were inoculated by a one-week- 
old culture of $A$. platensis EG5 to obtain initial biomass concentration of $0.064 \pm 0.015 \mathrm{~g}$ $\mathrm{L}^{-1}$ dry weight biomass (DWB); dried at $60^{\circ} \mathrm{C}$ ). The culture flasks were incubated at $28 \pm$ $2^{\circ} \mathrm{C}$ under a continuous light intensity of $3.5 \pm 0.2 \mathrm{Klux}$. The growth was determined as means of DWB $\left(\mathrm{g} \mathrm{L}^{-1}\right)$ every two days for ten days incubation period.

Table 2: The text treats of manure media.

\begin{tabular}{lcccc}
\hline $\begin{array}{l}\text { Manure } \\
\text { media treats }\end{array}$ & $\begin{array}{c}\text { Manure sock solution } \\
\left(\mathrm{ml} \mathrm{L}^{-1}\right)\end{array}$ & $\begin{array}{c}\text { Manure powder } \\
\left(\mathrm{g} \mathrm{L}^{-1}\right)\end{array}$ & $\begin{array}{c}\text { Nitrogen } \\
\left(\mathrm{mg} \mathrm{L}^{-1}\right)\end{array}$ & $\begin{array}{c}\text { Phosphorus } \\
\left(\mathrm{mg} \mathrm{L}^{-1}\right)\end{array}$ \\
\hline Treat I & 2.0 & 0.4 & 67.2 & 12.6 \\
Treat II & 4.0 & 0.8 & 134.4 & 25.2 \\
Treat III & 8.0 & 1.6 & 268.8 & 50.2 \\
Treat IV & 16 & 3.2 & 537.6 & 100.8 \\
Treat V & 32 & 6.4 & 1075.2 & 201.6 \\
Treat VI & 64 & 12.8 & 2150.4 & 203.2 \\
\hline
\end{tabular}

\section{Analysis of microalga biomass}

The protein content was estimated in A. platensis EG5 biomass cultivated on Zarrouk's and manure treats media at days 2, 6 and 10 of growth using Lowry's method (Lowry et al., 1951). Also, the concentrations of the metals; iron (Fe), magnesium ( $\mathrm{Mg})$, zinc $(\mathrm{Zn})$, copper $(\mathrm{Cu})$ and manganese $(\mathrm{Mn})$ were measured in A. platensis EG5 biomass at the end of incubation time. The metals were measured according to AOAC (2000) official method 985.01 using atomic absorption spectrophotometry (Shimadzu AA-6200).

\section{Verification experiment for large scale production of $\boldsymbol{A}$. platensis EG5}

The manure medium Treat IV, with the concentration of $3.2 \mathrm{~g} \mathrm{~L}^{-1}$, maintained the highest biomass and protein content, so this medium treat was used for the large scale production of A. platensis EG5. A fibreglass open pond with dimensions of $2.5 \mathrm{~m} \times 1.5 \mathrm{~m}$ and culture capacity of $1.0 \mathrm{~m}^{3}$ (Figure 1) was used for the large scale mass production. The open pond supported with a constant stirring system consists of paddle wheels and air pump, to ensure the continuous mixing, aeration and recirculation of the culture. For mass production, the open pond was filled with 500 litres manure medium (490 litres of pre-sterilized tap water and eight litres of the manure stock solution). The prepared medium was inoculated by a fresh culture of A. platensis EG5 cultivated on manure medium (Figure 1). The culture was incubated for two weeks and then refreshed by 500 litres of manure medium to obtain $1.0 \mathrm{~m}^{3}$ culture volume. After another two weeks, about $80 \%$ of the A. platensis EG5 culture was harvested by filtration through frame lined with plankton net fabric ( $3 \mu \mathrm{m} \mathrm{Mesh)} \mathrm{(Figure} \mathrm{1)} \mathrm{and} \mathrm{the} \mathrm{culture} \mathrm{was} \mathrm{refreshed} \mathrm{by} 1 / 2$ strength manure medium. The mass production process was continued for two months during the summer season, and the biomass productivity was estimated every two weeks. The air temperature during the cultivation period fluctuated between 32 and $42^{\circ} \mathrm{C}$ and the culture temperature fluctuated between 28 and $36^{\circ} \mathrm{C}$. Meanwhile, the light intensity fluctuated between 102.45 and 113.24 Klux. The protein content in the harvested biomass was estimated using Lowry's method (Lowry et al., 1951) and the amino acid profiles of $A$. platensis EG5 cultivated on Zarrouk's and manure media were determined according to AOAC Method No.982.30E (AOAC, 2011). 


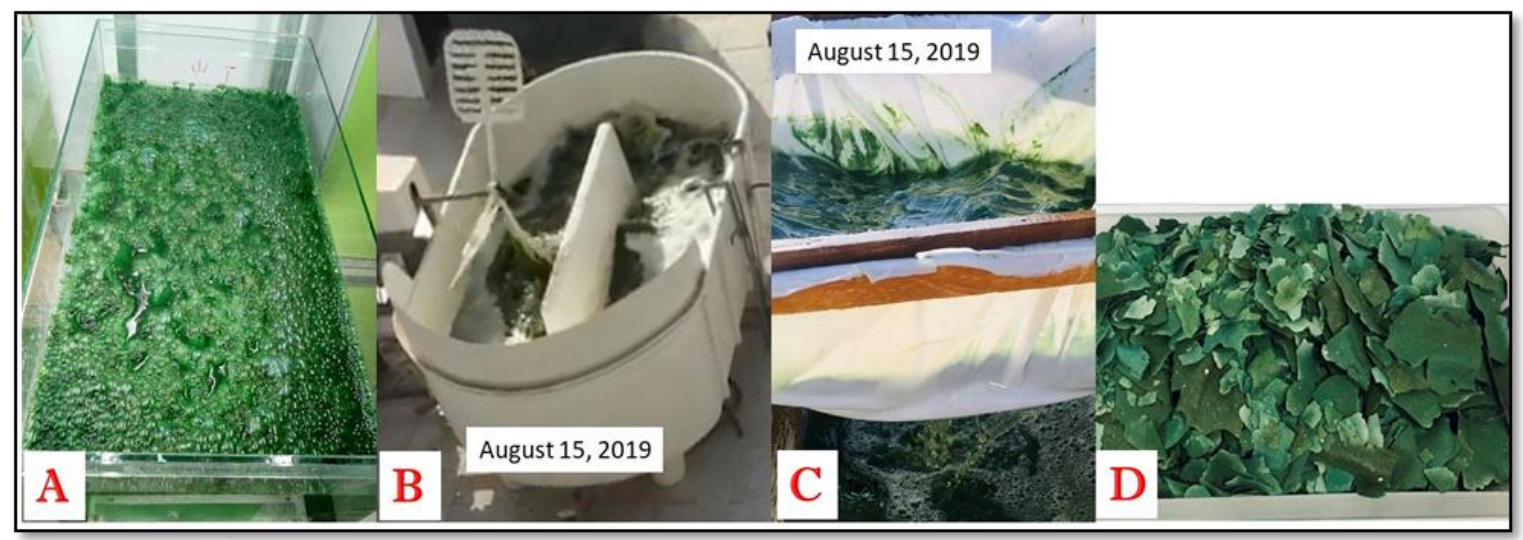

Figure 1: Large scale mass production of Arthrospira platensis EG5 on manure medium. A) Prepared inoculum of $A$. platensis EG5 cultivated in glass tanks with 20 Littre capacity, B) Cultivation in the fibreglass open pond, C) Harvesting process by plankton net fabric $(3 \mu \mathrm{m}$ Mesh) and D) Dried biomass of A. platensis EG5.

\section{Statistical analysis}

All the experiments were run in triplicate. The collected data were statistically analyzed by Tukey test to compare means using Statistical Package (Statistix 8.1). The level of significant difference was set at $P \leq 0.05$.

\section{RESULTS}

\section{Cultivation on manure media}

The growth curves of Arthrospira platensis EG5 cultivated on different concentrations of manure media vis the standard control Zarrouk's medium are shown in Figure 2. As seen from these curves, Treats III, IV, V and VI enhanced the growth of $A$. platensis over that recorded with Zarrouk's medium $\left(0.54 \pm 0.15 \mathrm{~g} \mathrm{~L}^{-1}\right)$ during the entire period of the experiment, giving the maximum value of $0.78 \pm 0.12 \mathrm{~g} \mathrm{~L}^{-1}$, for Treat IV (3.2 $\mathrm{g}$ manure $\left.\mathrm{L}^{-1}\right)$ followed by Treat V $\left(0.696 \pm 0.06 \mathrm{~g} \mathrm{~L}^{-1}\right)$. Meanwhile, both of Treats I and II suppressed the growth. Protein content revealed that Zarrouk's medium supported higher production of protein $\left(53.5 \pm 6.6 \mathrm{~g} 100 \mathrm{~g}^{-1}\right.$ dry biomass $)$ than those produced by all Treats (except Treats I and II) with nonsignificant difference $(P>0.05)$, especially for Treats IV

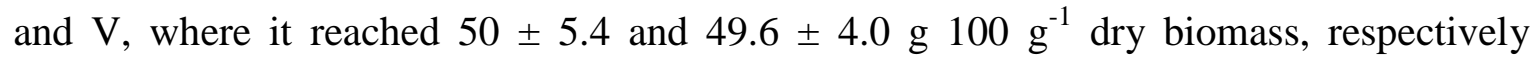
(Figure 3). 
A
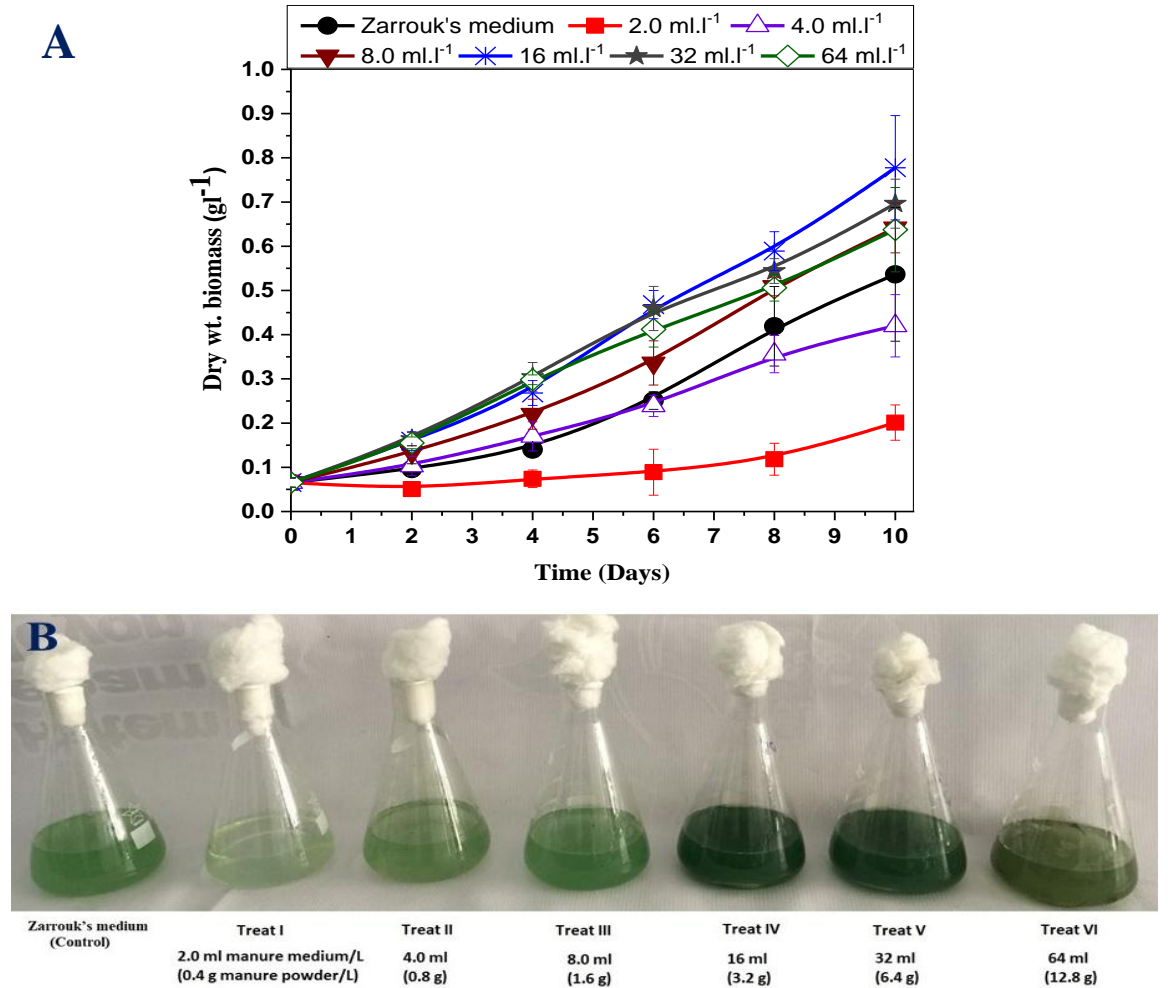

Figure 2: Changed in growth of Arthrospira platensis EG5 grown on Zarrouk's and different treats of manure media (A) and A. platensis EG5 growth at day ten (B).

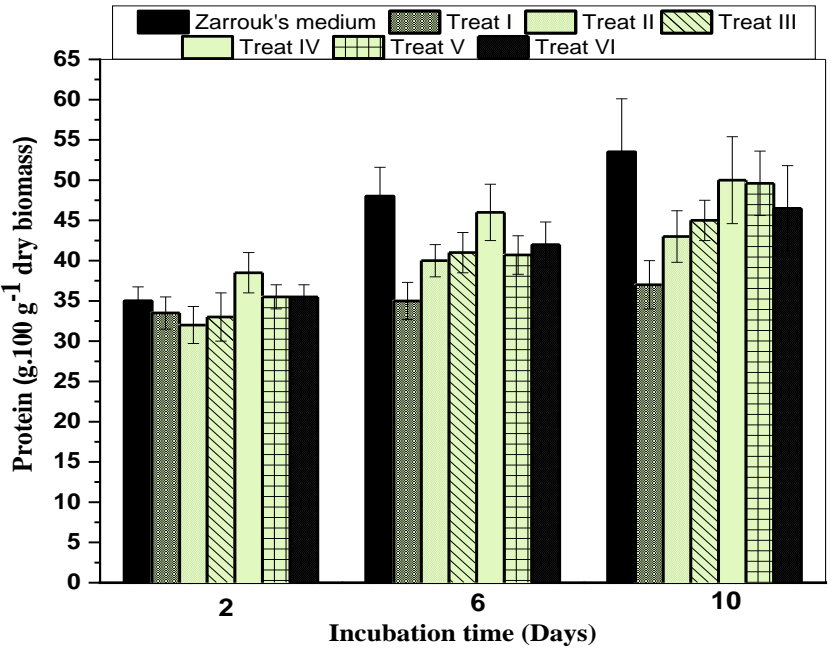

Figure 3: Protein content of Arthrospira platensis EG5 grown on Zarrouk's and different treats of manure media.

Table (3) shows the effect of manure media concentration on the accumulation of heavy metals; $\mathrm{Fe}, \mathrm{Zn}, \mathrm{Cu}, \mathrm{Mg}$ and $\mathrm{Mn}$ in A. platensis EG5 biomass. Treat I $\left(0.4 \mathrm{~g} \mathrm{~L}^{-1}\right)$ maintained the lowest concentrations of heavy metals which gradually increased by increasing manure concentration in the medium until the concentration of $1.6 \mathrm{~g} \mathrm{~L}^{-1}$ (Treat 
III). It is noticeable that $\mathrm{Fe}, \mathrm{Zn}$ and $\mathrm{Mn}$ obtained their maximum concentration $(124.75 \pm$ $3.75,0.885 \pm 0.105$ and $2.91 \pm 0.82 \mathrm{mg} 100 \mathrm{~g}^{-1}$, respectively) with Treat III, and then decreased with the higher concentrations of manure. While $\mathrm{Cu}$ gave its maximum $(0.60 \pm$ $\left.0.08 \mathrm{mg} 100 \mathrm{~g}^{-1}\right)$ with Treat IV and Mg with Treat V $\left(692.5 \pm 50.5 \mathrm{mg} 100 \mathrm{~g}^{-1}\right)$. It is of

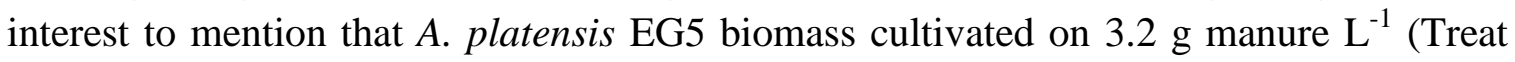
IV), which gave the highest biomass production for all Treats, accumulate higher concentrations of heavy metals than those recorded for Zarrouk's medium, especially for $\mathrm{Mg}\left(668.5 \pm 66.5 \mathrm{mg} 100 \mathrm{~g}^{-1}\right)$ compared to $277.5 \pm 30.5 \mathrm{mg} 100 \mathrm{~g}^{-1}$ with Zarrouk's medium (Table 3).

Table 3: Heavy metals concentrations in Arthrospira platensis EG5 cultivated on Zarrouk's and different treats of manure media.

\begin{tabular}{lccccc}
\hline \multirow{2}{*}{ Media } & \multicolumn{5}{c}{ Concentration $\left(\mathrm{mg} 100 \mathrm{~g}^{-1}\right)$} \\
\cline { 2 - 6 } & $\mathrm{Fe}$ & $\mathrm{Zn}$ & $\mathrm{Cu}$ & $\mathrm{Mg}$ & $\mathrm{Mn}$ \\
\hline Zarrouk's & $93.25 \pm 6.95$ & $1.05 \pm 0.215$ & $0.42 \pm 0.105$ & $277.5 \pm 30.5$ & $2.76 \pm 0.78$ \\
medium & & $0.740 \pm 0.151$ & $0.485 \pm 0.075$ & $260.5 \pm 27.5$ & $2.34 \pm 0.71$ \\
Treat I & $41.65 \pm 5.75$ & $0.810 \pm 0.140$ & $0.56 \pm 0.07$ & $336.5 \pm 27.5$ & $2.60 \pm 0.78$ \\
Treat II & $106.3 \pm 9.4$ & $0.885 \pm 0.105$ & $0.58 \pm 0.07$ & $559.5 \pm 10.5$ & $2.91 \pm 0.82$ \\
Treat III & $124.75 \pm 3.75$ & $0.865 \pm 0.045$ & $0.60 \pm 0.08$ & $668.5 \pm 66.5$ & $2.87 \pm 0.67$ \\
Treat IV & $116.5 \pm 7.5$ & $0.535 \pm 0.065$ & $0.58 \pm 0.04$ & $692.5 \pm 50.5$ & $2.69 \pm 0.75$ \\
Treat V & $86.6 \pm 9.8$ & & & & \\
\hline
\end{tabular}

\section{Large scale production of Arthrospira platensis EG5.}

The productivity of A. platensis EG5 on Treat IV manure medium for continuous large scale biomass production was studied for three continuous culturing cycles. The mean biomass production was $1.11,1.42$ and $1.35 \mathrm{~kg} \mathrm{~m}^{-3}$ for the $1^{\text {st }}, 2^{\text {nd }}$ and $3^{\text {rd }}$ harvested biomass, respectively. Also, the harvested biomass maintained a high protein content of

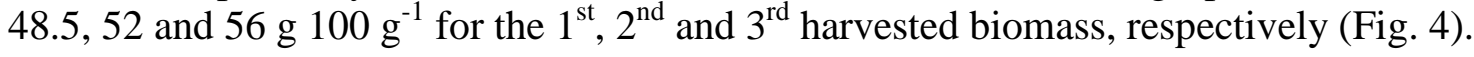

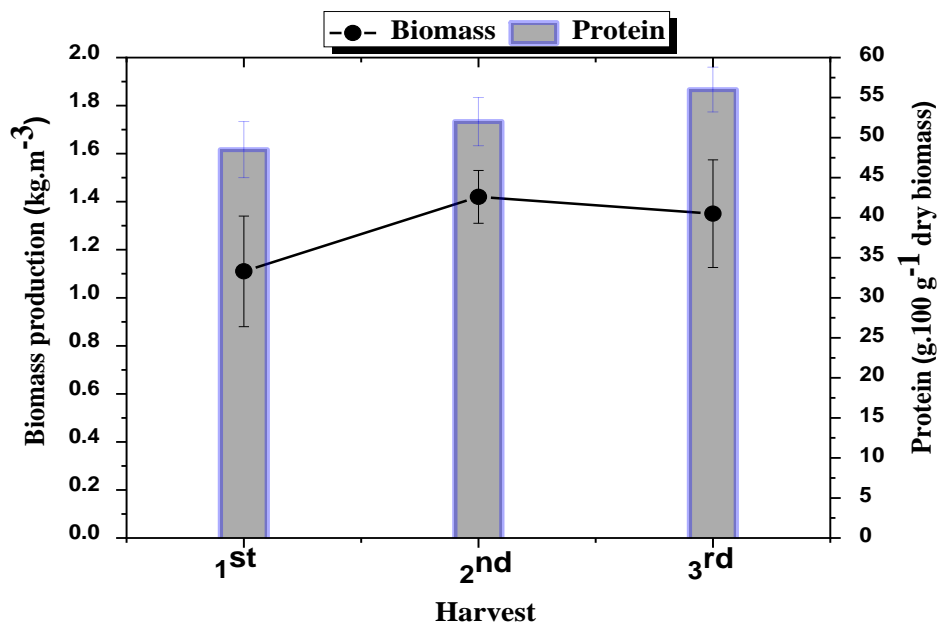

Figure 4: Biomass productivity and protein content of Arthrospira platensis EG5 cultivated on manure medium under field conditions. 


\section{Amino acids profile}

It is well known that the protein quality depends on its essential amino acid content. Amino acid profiles of A. platensis EG5 grown on Zarrouk's and manure media are given in Table 4. The essential amino acids (EAA) of A. platensis EG5 biomass cultivated on

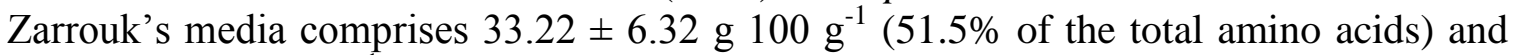

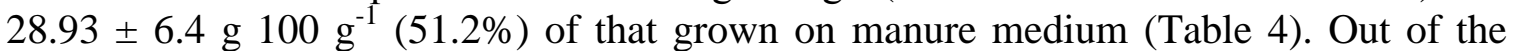
identified EAA, leucine, isoleucine, lysine, phenylalanine, threonine and valine were detected in high concentrations. The EAA content of A. platensis grown on Zarrouk's

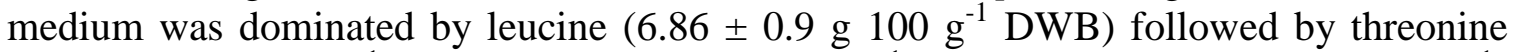

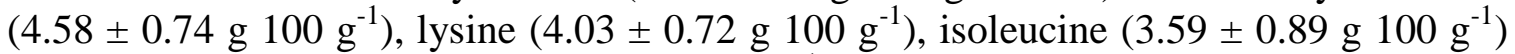

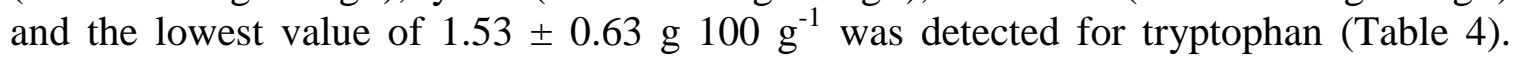
Meanwhile, the highest amounts of EAA in A. platensis grown on manure medium was

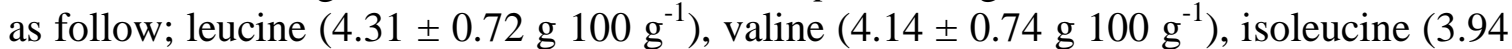

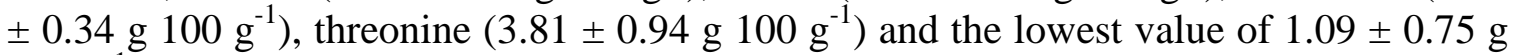
$100 \mathrm{~g}^{-1}$ was detected for histidine (Table 4). Glutamic acid, Aspartic acid, Alanine, and glycine were the highest detected non-essential amino acids (NEAA) (Table 4). Glutamic acid was the major amino acid in A. platensis EG5 grown on Zarrouk's and manure

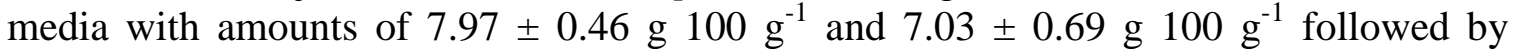

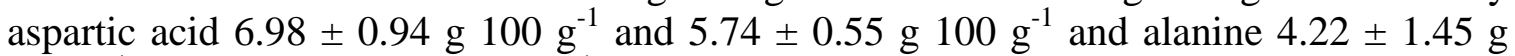

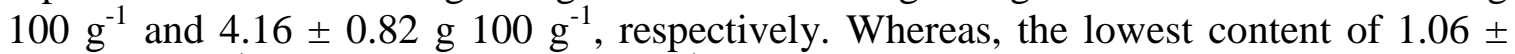

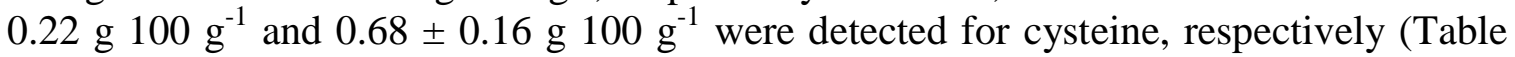
4).

Table 4: Amino acid composition of Arthrospira platensis EG5 cultivated on Zarrouk's and manure media. Data are the mean of 2 determinations of 2 different harvest \pm SE.

\begin{tabular}{lcccc}
\hline \multirow{2}{*}{ Amino Acid } & \multicolumn{2}{c}{ Zarrouk's Medium } & \multicolumn{2}{c}{ Manure medium } \\
\cline { 2 - 5 } & \% of DWB1 & \% of total AA² & \% of DWB & \% of total AA \\
\hline Essential amino acids (EAA): & $3.44 \pm 1.33$ & 5.26 & $2.46 \pm 1.01$ & 4.43 \\
Arginine & - & - & $1.09 \pm 0.75$ & 1.96 \\
Histidine & $3.59 \pm 0.89$ & 5.49 & $3.94 \pm 0.34$ & 7.1 \\
Isoleucine & $6.86 \pm 0.91$ & 10.5 & $4.31 \pm 0.72$ & 7.77 \\
Leucine & $4.03 \pm 0.72$ & 6.17 & $3.63 \pm 1.27$ & 6.54 \\
Lysine & $2.17 \pm 0.68$ & 3.32 & $1.47 \pm 0.57$ & 2.65 \\
Methionine & $3.78 \pm 1.23$ & 5.78 & $3.54 \pm 1.07$ & 6.38 \\
Phenylalanine & $4.58 \pm 0.74$ & 7.01 & $3.81 \pm 0.94$ & 6.87 \\
Threonine & $1.53 \pm 0.63$ & 2.34 & & - \\
Tryptophan & $3.24 \pm 0.52$ & 4.96 & $4.14 \pm 0.74$ & 7.46 \\
Valine & & & & \\
Nonessential amino acids (NEAA): & $4.22 \pm 1.45$ & 6.46 & $4.16 \pm 0.82$ & 7.5 \\
Alanine & $6.98 \pm 0.94$ & 12.2 & $5.74 \pm 0.55$ & 10.3 \\
Aspartic acid & $1.06 \pm 0.22$ & 1.62 & $0.68 \pm 0.16$ & 1.23 \\
Cysteine & & &
\end{tabular}




\begin{tabular}{lcccc} 
Glutamic acid & $7.97 \pm 0.46$ & 12.2 & $7.03 \pm 0.69$ & 12.7 \\
Glycine & $3.12 \pm 0.21$ & 4.77 & $2.66 \pm 0.23$ & 4.79 \\
Proline & $2.45 \pm 0.21$ & 3.75 & $2.72 \pm 0.21$ & 4.9 \\
Serine & $3.07 \pm 0.38$ & 4.7 & $2.86 \pm 0.58$ & 5.16 \\
Tyrosine & $2.27 \pm 0.22$ & 3.47 & $1.24 \pm 0.18$ & 2.24 \\
\hline Total amino acid (TAA) & $\mathbf{6 4 . 3 6} \pm \mathbf{0 . 7 4}$ & & $\mathbf{5 5 . 4 8 \pm 1 0 . 8 3}$ & \\
EAA & $\mathbf{3 3 . 2 2} \pm \mathbf{6 . 3 2}$ & & $\mathbf{2 8 . 3 9} \pm \mathbf{6 . 4}$ & \\
NEAA & $\mathbf{3 1 . 1 4} \pm \mathbf{4 . 4 2}$ & $\mathbf{2 7 . 0 9 \pm 4 . 4 3}$ & \\
\hline
\end{tabular}

1 Percent of amino acid (AA) in dry weight biomass (DWB), 2 Percent of AA to total amino acid (TAA).

\section{DISCUSSION}

The growing population is always accompanied by a terrible increase in the need for economical renewable alternative food resources. The present study aims to obtain an animal feed with high protein nutritional value and economic cost. Animal wastes had been known since ancient times as a rich and costless source of organic fertilizers that can be used for mass production of algae which used as animal and fish feed (Zhou $\boldsymbol{e t}$ al., 2012). The obtained results clarified that varying the animal manure concentration in $A$. platensis EG5 culture medium had a significant influence on biomass production, where, the manure medium with the concentrations of 1.6, 3.2, 6.4 and even $12.8 \mathrm{~g} \mathrm{~L}^{-1}$, stimulated the biomass production by $19.6,44.9,29.8,18.8 \%$ respectively, compared to Zarrouk's medium (Figure 2). Costa et al. (2004) in his trial to increase biomass by addition of urea reported that high nitrogen content stimulates growth and biomass productivity of algae cultures. This hypothesis is consistent with the obtained results; as the analysis of animal wastes showed significant high nitrogen content $\left(168 \mathrm{mg} \mathrm{g}^{-1}\right.$ manure powder). Costa et al. (2001) and Madkour et al. (2012b) also noted that different nitrogen sources or/and concentrations affected the development of A. platensis. Beside of that, the obtained results clarified the efficiency of animal manure media for biomass production in large-scale during three continuous culturing cycles and under field conditions (Figure 4) indicating that animal manure was the factor with the greatest influence on biomass production. Anent the importance of protein as an essential component of the biomass, Treat IV gave the highest protein content $(38.5 \pm 2.2 \%$ of DWB) after two days (Figure 3), however after 6 and 10 days Zarrouk's medium supported higher protein content $(53.5 \pm 6.6 \%$ of DWB), but with nonsignificant differences $(P>0.05)$ compared to $50 \pm 5.4 \%$ of DWB at Treat IV manure medium. In this context, Koru and Cirik (2003) reported that the variation in protein content referred to the differences in the nutrition media, especially the concentration of nitrogen (Ungsethaphand, et al., 2007, 2009). These findings reflect the economic advantage of using animal manure as an alternative source of nutrients in the cultivation media without causing a significant decrease in protein content and these results were ensured during large scale production of A. platensis G5 on manure medium (Figure 4). 
With regards to concentration of metals in produced A. platensis EG5, the concentrations of Fe and $\mathrm{Mg}$ in A. platensis cultivated on Treat IV $(1165$ and $6685 \mathrm{mg} / \mathrm{kg}$ DWB, respectively) were higher than the requirement of many animals (30 - 50 and 1200 - $1800 \mathrm{mg} / \mathrm{kg} \mathrm{DM}$, respectively) and the maximum tolerable level (500 and $6000 \mathrm{mg} / \mathrm{kg}$ DM, respectively) (NRC, 1985, 2005, 2007; McDowell, 2003). However, the high level of Fe in A. platensis EG5 does not pose a harm for animal feed where high concentration of Fe was reported to reduce the uptake of $\mathrm{Cu}, \mathrm{P}, \mathrm{Zn}$, and $\mathrm{Mn}$ (McDowell, 2003; Suttle, 2010). In contradiction, Zinc in A. platensis EG5 cultivated on Treat IV was lower (8.65 $\mathrm{mg} / \mathrm{kg}$ DWB) than the sheep requirements $(20$ - $33 \mathrm{mg} / \mathrm{kg} \mathrm{DM})$ (NRC, 1985, 2007; McDowell, 2003). The mean concentration of $\mathrm{Cu}$ in A. platensis EG5 biomass $(6.0 \mathrm{mg} / \mathrm{kg}$ DM) was close to sheep requirements $(7-15 \mathrm{mg} / \mathrm{kg} \mathrm{DM})$ according to the reports of NRC (1985, 2007) and McDowell (2003). The range of Mn concentration in A. platensis EG5 biomass (22 and $35.4 \mathrm{mg} / \mathrm{kg}$ DWB) was compatible with the required range of sheep (20 - 40 mg/kg DM) (NRC, 1985, 2007; McDowell, 2003; McDowell, 2003; Suttle, 2010). In general, the measured metals concentrations in A. platensis EG5 cultivated on Treat IV were in good agreement with the range of animal feed requirements reported by NRC (1985, 2007) and McDowell (2003).

The nutritional quality of protein depends mainly on its essential amino acid composition (Becker, 2007; WHO, 2007). The microalgae protein contains all essential amino acids and some species can be compared with soy and egg protein (GallandIrmouli et al., 1999). It is obvious from the results of amino acid profile that A. platensis EG5 cultivated on manure medium are a good source of the essential amino acids; arginine, leucine, isoleucine, lysine, methionine, phenylalanine, threonine and valine and their levels are in agreement with that reported by Habib et al. (2008). In addition, the percent of the amino acids (AA) to the total amino acids (TAA) and to the dry weight biomass (DWB) of A. platensis EG5 grown on manure medium (Table 4) exceeded the amino acids concentrations required by different animals reported by the National Research Council $(\mathbf{1 9 7 7 ,}$ 2011) (Table 5).

Table 5: Amino Acid Requirements of Seven Animals (Adapted from the National Research Council, 1977)

\begin{tabular}{|c|c|c|c|c|c|c|c|}
\hline Amino acid & Eel fingerling & Carp fry & $\begin{array}{c}\text { Channel } \\
\text { catfish }\end{array}$ & $\begin{array}{l}\text { Chinook } \\
\text { salmon } \\
\text { fingerling }\end{array}$ & Chick & Young Pig & Rat \\
\hline Arginine & $3.91(1.7)^{2}$ & $4.3(1.65)$ & & $6.0(2.4)$ & $6.1(1.1)$ & $1.5(0.2)$ & $1.0(0.2)$ \\
\hline Histidine & $1.9(0.8)$ & & & $1.8(0.7)$ & $1.7(0.3)$ & $1.5(0.2)$ & $2.1(0.4)$ \\
\hline Isoleucine & $3.6(1.5)$ & $2.6(1.0)$ & & $2.2(0.9)$ & $4.4(0.8)$ & $4.6(0.6)$ & $3.9(0.5)$ \\
\hline Leucine & $4.1(1.7)$ & $3.9(1.5)$ & & $3.9(1.6)$ & $6.7(1.2)$ & $4.6(0.6)$ & $4.5(0.9)$ \\
\hline Lysine & $4.8(2.0)$ & & $5.1(1.23)$ & $5.0(2.0)$ & $6.1(1.1)$ & $4.7(0.65)$ & $5.4(1.0)$ \\
\hline Methionine $\underline{3}$ & $4.5(2.1)^{\underline{3}}$ & $3.1(1.2)$ & $2.3(0.56)$ & $4.0(1.6)^{4}$ & $4.4(0.8)$ & $3.0(0.6)$ & $3.0(0.6)$ \\
\hline Phenylalanine 5 & & & & $5.1(2.1)^{6}$ & $7.2(1.3)$ & $3.6(0.45)$ & $5.3(0.9)$ \\
\hline Threonine & $3.6(1.5)$ & & & $2.2(0.9)$ & $3.3(0.6)$ & $3.0(0.4)$ & $3.1(0.2)$ \\
\hline Tryptophan & $1.0(0.4)$ & & & $0.5(0.2)$ & $1.1(0.2)$ & $0.8(0.2)$ & $1.0(0.2)$ \\
\hline Valine & $3.6(1.5)$ & & & $3.2(1.3)$ & $4.4(0.8)$ & $3.1(0.4)$ & $3.1(0.4)$ \\
\hline $\begin{array}{l}\% \text { of total protein in } \\
\text { the diet }\end{array}$ & 42 & 38.5 & 24 & $40-41$ & 18 & $13-20$ & $13-20$ \\
\hline
\end{tabular}

1 Percent of AA to TAA, $\underline{2}$ Percent of AA in dry diet, $\underline{3}$ In the absence of cysteine, $\underline{4}$ Methionine plus cysteine, $\underline{5}$ In the absence of tyrosine, 6 Phenylalanine plus tyrosine. 


\section{CONCLUSION}

The biotechnological applications of $A$. platensis require intensive cultivation for mass production, taking into consideration the economic factors. Based on the promising results of economic mass production of $A$. platensis EG5 on livestock manure, we would recommend future detailed studies on using the livestock manure for commercial-scale cultivation of microalgae as a protein source to enhance the nutritional quality of fish and animals diets economically and sustainably.

\section{REFERENCES}

Abdel-Aal, E.I. (2013). Biotechnological studies on Egyptian isolates of Botryococcus braunii: Botryococcus braunii as a renewable feedstock of hydrocarbon biofuel. LAP Lambert Academic Publishing, pp 336.

Abdel-Aal, E.I.; Haroon, A.M. and Mofeed, J. (2015). Successive solvent extraction and GC-MS analysis for the evaluation of the phytochemical constituents of the filamentous green alga Spirogyra longata. Egypt. J. Aquat. Res., 41: 233-246. https://doi.org/10.1016/j.ejar.2015.06.001

Abdel-Aal, E.I. and Mofeed, J. (2015). Optimization of medium components for high biomass and lipid production of the freshwater diatom Tryblionella hungarica NIOFDM-017 by using Plackett-Burman design. Egypt. J. Exp. Biol. (Bot.), 11(1): 41 - 50.

Abdel-Daim, M.M.; Ali, M.S.; Madkour, F.F. and Elgendy, H. (2020). Oral Spirulina platensis attenuates hyperglycemia and exhibits antinociceptive effect in streptozotocin-induced diabetic neuropathy rat model. J. Pain Res., 13: 2289-2296.

Abdel-Daim, M.M.; Farouk, S.M.; Madkour, F.F. and Azab, S.S. (2015). Antiinflammatory and immunomodulatory effects of Spirulina platensis in comparison to Dunaliella salina in acetic acid-induced rat experimental colitis. Immunopharm. Immunotoxic. 37(2): 126-139. DOI: 10.3109/08923973.2014.998368.

Abdel-Hamid, M.I.; Abdel-Aal E.I. and Abdel-Mogib, M. (2019). Isolation and characterization of new Botryococcus braunii (Trebouxiophyceae) isolates. Renew. Energy, 141:782-790. https://doi.org/10.1016/j.renene.2019.04.048

Abdel-Hamid, M.I.; Abdel-Aal, E.I. and Azzab, Y.A. (2014). Spatial Quality Improvement of a Toxic Industrial Effluent, Based on Physico-Chemistry, Algal Community Changes and Algal Bioassay. Afr. J. Aquat. Sci., 39(1): 1-16. DOI: $10.2989 / 16085914.2013 .870524$

Abdel-Hamid, M.I.; Belal, S.A.; Azab, Y.A.; Abdel-Mogib, M. and Abdel-Aal, E.I. (2015a). Nutritional value of some selected green microalgae. J. Environ. Sci. (JOESE 5), 44(3): 455-467.

Abdel-Hamid, M.I.; Salama, S.A.; Azab, Y.A.; Hussein, M.H. and Abdel-Aal, E.I. (2015b). Studies on biomass of different Scenedesmus Species as feasible feedstock of biodiesel. J. Environ. Sci. (JOESE 5), 44(1): 143-160.

Abdel-Hamid, M.I.; Mousa, M.A.; Abdel-Aal, E.I. and El-Zamek, F.-E. (2016). Sustainable biomass production of the marine microalga Chlorella salina as live food for the rotifer Brachionus plicatilis. J. Environ. Sci. (JOESE 5), 45(1): 39-52. 
Abdel-Hamid, M.I.; El-Amier, Y.A.; Abdel-Aal, E.I. and El-Far, G.M. (2017). Water Quality Assessment of El-Salam Canal (Egypt) Based on Physico-Chemical Characteristics in Addition to Hydrophytes and their Epiphytic Algae. Int J Eco. Develop. Res., 3(1): 028-043.

Abdel Gawad, S.S. and Abdel-Aal, E.I. (2018). Impact of Flood Cycle on Phytoplankton and Macroinvertebrates Associated with Myriophyllum spicatum in Lake Nasser Khors (Egypt). J. Biol. Sci., 18: 51-67. DOI: 10.3923/jbs.2018.51.67

AOAC, Official Methods of Analysis (2000). The Association of Official Analytical Chemists, $17^{\text {th }} \mathrm{Ed}$, Inc. Washington, USA.

AOAC (2011). The Association of Official Analytical Chemists, $18^{\text {th }}$ Ed, Arlington, USA. APHA, American Public Health Association (2005). Standard methods for examination of water and wastewater. $21^{\text {st }}$ Ed. Standard Methods is a joint publication of the American Public Health Association (APHA), the American Water Works Association (AWWA), and the Water Environment Federation (WEF). Washington DC, USA.

Babadzhanov, A.S.; Abdusamatova, N.; Yusupova, F.M.; Faizullaeva, N.; Mezhlumyan, L. and Malikova, M. (2004). Chemical Composition of Spirulina platensis Cultivated in Uzbekistan. Chem. Nat. Comp., 40(3): 276-279. DOI: 10.1023/B:CONC.0000039141.98247.e8

Bansemir, A.; Blume, M.; Schröder, S. and Lindequist, U. (2006) Screening of cultivated seaweeds for antibacterial activity against fish pathogenic bacteria. Aquaculture 252:79-84

Becker, W. (2004). Microalgae in human and animal nutrition. In: Richmond A (ed) Handbook of microalgal culture. Blackwell, Oxford, pp 312-351

Becker, E.W. (2007). Microalgae as a source of protein. Biotechnol. Adv., 25(2): 207-210.

Binaghi, L.; Del Borghi, A.; Converti, A. and Del Borghi, M. (2003). Batch and fedbatch uptake of carbon dioxide by Spirulina platensis. Process Biochem, 38(9):13411346. https://doi.org/10.1016/S0032-9592(03)00003-7

Chaiklahan, R.; Chirasuwan, N.; Siangdung, W.; Paithoonrangsarid, K. and Bunnag, B. (2010). Cultivation of Spirulina platensis using pig wastewater in a semi-continuous process. J. Microbiol. Biotechnol., 20(3): 609-

14. DOI: $10.4014 / \mathrm{jmb} .0907 .07026$

Cheunbarn, S. and Peerapornpisal, Y. (2010). Cultivation of Spirulina platensis using Anaerobically Swine Wastewater Treatment Effluent. Int J Agric Biol., 12(4): 586590.

Costa, J.A.V.; Colla L.M., and Filho P.F.D. (2004). Improving Spirulina platensis biomass yield using a fed-batch process, Bioresour. Technol., 92(3): 237-241. https://doi.org/10.1016/j.biortech.2003.09.013

Costa, J. A.V.; Cozza, K.L.; Santos, L.O. and Magagnin, G. (2001). Different nitrogen sources and growth responses of Spirulina platensis in microenvironments. World $\mathbf{J}$. Microbiol. Biotechnol. 17(5):439-442. https://doi.org/10.1023/A:1011925022941

Davis, A.R. (1977). Principles of Oceanography, $2^{\text {nd }}$ ed., Addison-Wesley Pub. Co. pp 505.

Deyab, M.A.; Mofeed, J.; Abd El-Halim, E.H. and Ward, F. (2020). Antiviral activity of five filamentous cyanobacteria against coxsackievirus B3 and rotavirus. Arch. Microbio., 202:213-223.

El-Sheekh, M.; El-Shourbagy, I.; Shalaby, S. and Hosny S. (2014). Effect of Feeding Arthrospira platensis (Spirulina) on Growth and Carcass Composition of Hybrid Red 
Tilapia (Oreochromis niloticus x Oreochromis mossambicus). Turkish J. Fish. Aquat. Sci., 14: 471-478. DOI: 10.4194/1303-2712-v14_2_18

Galland-Irmouli, A.V.; Fleurence, J.; Lamghari, R.; Luçon, M.; Rouxel, C.; Barbaroux, O.; Guéant, J.L. (1999). Nutritional value of proteins from edible seaweed Palmaria palmata (dulse). J. Nutr. Biochem., 10(6): 353-359. DOI: 10.1016/s0955-2863(99)00014-5

Habib, M.A.B.; Parvin, M.; Huntington, T.C. and Hasan, M.R. (2008). A Review on Culture, Production and use of Spirulina as Food for Humans and Feeds for Domestic Animals and Fish. FAO Fisheries and Aquaculture Circular. No. 1034. Rome, FAO.33p.

Kendirli, K. (2010). Spirulina Kültürlerinde Besin Elementlerinin Farkli Oranlarda Kullaniminin Kuru Madde, Protein ve Klorofil-a Düzeyine Etkisi. Department of biotechnology, Institute of Natural and Applied Sciences, University of Çukurova University, MSc Thesis. pp 79.

Khatoon, N. and Pal, R. (2015). Microalgae in Biotechnological Application: A Commercial Approach. In: Bahadur B., Venkat Rajam M., Sahijram L., Krishnamurthy K. (eds) Plant Biology and Biotechnology. Springer, New Delhi. https://doi.org/10.1007/978-81-322-2283-5_2

Koru, S., and Cirik, S. (2003). Spirulina platensis (Cyanophyceae) Mikroalg'inin Büyümesine ve Bazı Biyokimyasal Özelliklerine Sıcaklığın Etkisi, E.Ü. Su Ürünleri Dergisi, 20 (3-4); pp. 419-422.

Lowry, O.H.; Rosebrough, N.J.; Farr, A.L. and Randall R.J. (1951) Protein measurement with Folin phenol reagent. J. Biol. Chem., 193(1): 265-275.

Madkour, F.F.; El-Shoubaky, G.A. and Attia, M.E. (2019). Antibacterial activity of some seaweeds from the Red Sea coast of Egypt. Egypt. Aquat. Biol. Fish., 23(2): 265-274.

Madkour, F.F.; Khalil, W.F. and Dessouki, A.A. (2012a). Protective effect of ethanol extract of Sargassum dentifolium (Phaeophyceae) in carbon tetrachloride induced hepatitis in rats. Inter. J. Pharm. Pharmac. Sc., 4(3): 637-641.

Madkour, F.F.; Kamel, A.M. and Nassr, H.S. (2012b). Production and nutritive value of Spirulina platensis in reduced cost media. Egypt. J. Aquat. Res., 38(1): 51-57.

Markou, G.; Wang, L.; Ye, J. and Unc, A. (2018). Using agro-industrial wastes for the cultivation of microalgae and duckweeds: Contamination risks and biomass safety concerns. Biotechnol. Adv., 36(4):1238-1254. https://doi.org/10.1016/j.biotechadv.2018.04.003

McDowell, L.R. (2003). Minerals in animal and human nutrition. $2^{\text {nd }}$ ed. Elsevier, Amsterdam, the Netherlands.

Mitchell, S.A. and Richmond, A. (1988). Optimization of a growth medium for Spirulina based on cattle waste. Biol. Wastes, 25(1): 41-50. https://doi.org/10.1016/0269-7483(88)90126-7

Mofeed, J. (2017). Biosorption of heavy metals from aqueous industrial effluent by nonliving biomass of two marine green algae "Ulva lactuca and Dunaliella salina (Egyptian Isolates) as biosorbent. J. CATRINA. 16 (1):51-62.

Mofeed, J. (2019). Stimulating Gamma-Linolenic Acid Productivity by Arthrospira platensis (Spirulina platensis) Under Different Culture Conditions (Temperatures, 
Light Regime, and H2O2 stress). Egypt. Acad. J. Biol. Sci. (G. Microbiology), 11(1): 89-99.

Mofeed J. and Mosleh, Y.Y. (2013). Toxic responses and antioxidative enzymes activity of Scenedesmus obliquus exposed to fenhexamid and atrazine, alone and in mixture. Ecotoxico. Environ. Safety, 95: 234 - 240.

https://doi.org/10.1016/j.ecoenv.2013.05.023

Mofeed, J.; Sabry, A.-E. and Deyab M.A. (2019). Evaluation of Biochemical composition and bioactivity of two Egyptian Ulva sp.; a comparative study. Applied Phycology. Biosci. Res., 16 (4): $3801-3811$.

NRC, National Research Council (1977). Subcommittee on Warmwater Fishes, Nutrient requirements of warmwater fishes. Washington, D.C., National Academy of Sciences (Nutrient requirements of domestic animals) $78 \mathrm{p}$.

NRC. (1985). Nutrient requirements of sheep. $6^{\text {th }}$ rev. ed. Natl. Acad. Press, Washington, DC.

NRC. (2005). Mineral tolerance of animals. $2^{\text {nd }}$ rev. ed. Natl Acad. Press, Washington, DC.

NRC. (2007). Nutrient requirements of small ruminants: Sheep, goats, cervids, and New World camelids. Natl. Acad. Press, Washington, DC.

NRC (2011). Nutrient Requirements of Fish and Shrimp. National Research Council, The National Academies Press, Washington, D.C.

Pelizer, L.H.; Carvalho, J.C.M. and Moraes, I.O. (2015). Protein production by Arthrospira (Spirulina) platensis in solid state cultivation using sugarcane bagasse as support. Biotechnol. Rep., 5: 70-76. https://doi.org/10.1016/j.btre.2014.12.006

Petersen, S.O.; Sommer, S.G.; Béline, F.; Burton, C.; Dach, J.; Dourmad, J.Y.; Leip, A.; Misselbrook, T.; Nicholson, F.; Poulsen, H.D.; Provolo, G.; Sørensen, P.; Vinnerås, B.; Weiske, A.; Bernal, M.P.; Böhm, R.; Juhász, C. and Mihelic, R. (2007). Recycling of livestock manure in a whole-farm perspective. Livest. Sci. 112, 180-191. https://doi.org/10.1016/j.livsci.2007.09.001

Phang, S.M.; Miah, M.S.; Chu, W.L. and Hashim, M. (2000). Spirulina culture in digested sago starch factory waste water. J. Appl. Phycol., 12: 395-400. https://doi.org/10.1023/A:1008157731731

Pulz, O. and Gross, W. (2004): Valuable products from biotechnology of microalgae. Appl. Microbiol. Biotechnol., 65(6): 635-648. DOI: 10.1007/s00253-004-1647-x

Renaud, S.M.; Thinh, L.V. and Parry, D.L. (1999). The gross composition and fatty acid composition of 18 species of tropical Australia microalgae for possible use in mariculture. Aquac., 170(2):147-159. https://doi.org/10.1016/S0044-8486(98)00399-8

Shaaban-Desouki, S.A.; Deyab, M.A. and Mofeed, J. (2004). Phycological Assessment of water Quality of River Nile Delta-Egypt. Egypt. J. Phyco., 5: 19-34.

Suttle, N.F. (2010). Mineral Nutrition of Livestock. 4th Edition, CABI, Cambridge.

Ungsethaphand, T.; Peerapornpisal, Y. and Whangchai, N. (2009). Production of Spirulina platensis using dry chicken manure supplemented with urea and sodium bicarbonate. Maejo Int. J. Sci. Technol., 3(3): 379-387.

Ungsethaphand, T., Peerapornpisal, Y., Whangchai N. and Sardsud, U. (2007). Productivity and chemical composition of Spirulina platensis using dry chicken manure as nitrogen sources. Proceedings of the $19^{\text {th }}$ Annual Meeting of the Thai Society for Biotechnology, Bangkok, Thailand, pp. 43-48. 
Ward, B.; Dutkiewicz, S.; Jahn, O. and Follows, M.J. (2012). A size-structured foodweb model for the global ocean. Limnol. Oceanogr, 57(6): 1877-1891. https://doi.org/10.4319/1o.2012.57.6.1877

WHO (2007). Protein and Amino Acid Requirements in Human Nutrition. Report of a Joint FAO/WHO/ UNU Expert Consultation, WHO Technical Report Series 935. World Health Organization, Geneva, Switzerland.

Zarrouk, C. (1966). Contribution à l'étuded'unecyanophycée. Influence de Divers Facteurs Physiques et Chimiques Sur la Croissance et la Photosynthèse de Spirulina maxima. Ph.D. Thesis, Université De Paris, Paris.

Zhou, W.; Hu, B.; Li, Y.; Min, M.; Mohr, M.; Du, Z.; Chen, P. and Ruan R. (2012). Mass cultivation of microalgae on animal wastewater: a sequential two-stage cultivation process for energy crop and omega-3-rich animal feed production. Appl Biochem Biotechnol., 168(2):348-63. Doi: 10.1007/s12010-012-9779-4. 